\title{
Experimental Allergic Encephalomyelitis
}

\section{ISOLATION OF BASIC PROTEINS AND POLYPEPTIDES FROM CENTRAL NERVOUS TISSUE}

\author{
BY P. R. CARNEGIE, BEVERLEY BENCINA AND G. LAMOUREUX* \\ Russell Grimwade School of Biochemistry, University of Melbourne, and the \\ Walter and Eliza Hall Institute for Medical Research, Parkville, N. 2, Victoria, Australia
}

(Received 30 Jamuary 1967)

\begin{abstract}
1. Basic protein (mol.wt. 16500) and polypeptides (mol.wt. 3500) were isolated from bovine spinal cord by a procedure involving defatting, acid extraction of the defatted material and repeated chromatography on Sephadex G-50. Similar fractions were isolated from guinea-pig brain. 2. These fractions produced experimental allergic encephalomyelitis in guinea pigs. 3. The polypeptides appeared to be derived from a basic protein of myelin as a result of the action of an acid proteinase during extraction with acid. Similar proteolysis might also occur in the isolation of other biologically active polypeptides from acetone-dried powders of nervous tissue. The activity of the acid proteinase was lowered by defatting with chloroform-methenol. 4. Peptides from tryptic digests of encephalitogenic polypeptides and protein were also encephalitogenic, which suggests that the encephalitogenic determinant may be quite a short sequence of amino acids. 5. These encephalitogenic polypeptides are further examples of antigens of low molecular weight.
\end{abstract}

Experimental allergic encephalomyelitis, an autoimmune disease of the central nervous system, is produced in experimental animals by injection of extracts of central nervous tissue premixed with adjuvant. Paterson (1966), in a review on EAE, $\dagger$ has stressed that the identification and characterization of the antigen is of great importance in the elucidation of the immunological processes involved in this disesse. Many earlier immunological experiments are difficult to interpret as crude extracts of brain containing a multiplicity of potential antigens were used to produce EAE.

It has been established that the antigens which produce EAE (encephalitogens) can be extracted with dilute acid from central nervous tissue. However, there is considerable controversy about the composition and size of the encephalitogens. A basic protein has been isolated from guinea-pig brain (Kies, Murphy \& Alvord, 1961) and from purified myelin (Laatsch, Kies, Gordon \& Alvord, 1962). Hottle, Nedzel, Wright \& Bell (1949), Robertson, Blight \& Lumsden (1962), Nakro \& Roboz-Einstein (1965) and Lumsden, Robertson \&

* Present address: Institut de Microbiologie et d'Hygiène de l'Université de Montréal, Case Postale 100, Laval-desRapides, P. Québec, Canada.

$\uparrow$ Abbreviations: EAE, experimental allergic encephalomyelitis; BEP, bovine encephalitogenic polypeptide.
Blight (1964, 1966) studied encephalitogens which diffused through cellophan. Carnegie \& Lumsden $(1966,1967)$ isolated a group of basic encephalitogenic polypeptides from acetone-dried powders of bovine spinal cord. (In this paper polypeptides are defined as having mol.wt. between 1000 and 10000 and proteins mol.wt. greater than 10000; Synge, 1949.) The discovery that purified polypeptides of low molecular weight produce disease is of considerable importance in the understanding of the pathogenesis not only of EAE but also of other organ-specific autoimmune diseases for which EAE is a prototype (Paterson, 1966).

The long-term aim of this investigation is the elucidation of the amino acid sequence of the encephalitogenic determinant. This peper describes further fractionation of the group of polypeptides isolated by Carnegie \& Lumsden (1967) and their relationship to encephalitogenic basic protein. No attempt was made to isolate or account for all the encephalitogenic compounds in extracts of spinal cord; the aim was simply to isolate the smallest polypeptide capable of producing EAE. Indeed it is not possible to account quantitatively for all the encephalitogenio activity since the assay is primarily qualitative; for example, there is no difference in the response of groups of guinea pigs to doses of encephalitogen ranging from $50 \mathrm{ng}$. 
to 50 $\mathrm{g}$. (Lamoureux, Carnegie, McPherson \& Johnston, 1967b). The proteins and polypeptides described in this paper have been used in studies on immunological processes involved in EAE (Lamoureux, Carnegie \& McPherson, 1967a; Lamoureux et al. 1967b; Lamoureux, McPherson, Carnegie \& Mackay, 1967d; Lamoureux, McPherson \& Carnegie, 1967c).

\section{MATERIALS}

Sephadex G-50 fine and CM-Sephadex C-25 were from Pharmacia A.B., Uppsala, Sweden. Trypsin (lot no. 6111) was from Worthington Biochemical Corp., Freehold, N.J., U.S.A.; it was treated with chloromethyl 2-phenyl-L-1toluene- $p$-sulphonamidoethyl ketone (Wang \& Carpenter, 1965) to inhibit any chymotryptic activity. Chymotrypsin (type II) was from Sigma Chemical Co., St Louis, Mo., U.S.A. Freund's complete adjuvant was from Difco Lab., Detroit, Mich., U.S.A. Polyacrylamide gels were prepared from AM-9 Chemical Grout, American Cyanamid Co., Wayne, N.J., U.S.A.

Spinal cord was collected from adult steers immediately after slaughter and placed in ice. Guinea pigs were anaesthetized with chloroform and the brains removed and stored at $-20^{\circ}$.

\section{METHODS}

Preparation of acetone-dried powder. Fresh bovine spinal cord $(150 \mathrm{~g}$.) was stripped of meninges and homogenized with chilled acetone $(450 \mathrm{ml}$.) in an MSE Ato-Mix. The extract was filtered and the residue mixed with light petroleum (b.p. $\left.60-80^{\circ}\right)\left(300 \mathrm{ml}\right.$.) and left for $1 \frac{1}{2} \mathrm{hr}$. at room temp. After filtration the residue was again homogenized with acetone and dried in vacuo over paraffin wax and silica gel.

Preparation of 'basic fraction'. Portions of this acetonedried powder $(50 \mathrm{~g}$.) were homogenized for a few minutes with chilled $0.02 \mathrm{~N}-\mathrm{HCl}(500 \mathrm{ml}$.). The extracts were filtered and the residues re-extracted with $500 \mathrm{ml}$. of acid. The combined filtrates were pH3.7. Filtrates were carefully adjusted to $\mathrm{pH} 5$ with $2 \mathrm{~N}-\mathrm{NaOH}$ and stirred with $\mathrm{CM}$ Sephadex (25g.), in the $\mathrm{Na}^{+}$form, for $30 \mathrm{~min}$. The slurry was transferred to a column $(12 \mathrm{~cm} . \times 5 \mathrm{~cm}$.) and washed with 11. of water to remove neutral and acidic material. Basic proteins and polypeptides were eluted with $0 \cdot 1 \mathrm{~N}-\mathrm{HCl}$. The fractions corresponding to $900-1300 \mathrm{ml}$. of eluate contained approx. $90 \%$ of the total eluted protein and polypeptide; the proteins were eluted preferentially between 900 and $1050 \mathrm{ml}$. The above fractions $(900-1300 \mathrm{ml}$.) were pooled, adjusted to $\mathrm{pH} 7$ and added to $10 \mathrm{vol}$. of acetone. The precipitate which settled overnight was collected by filtration, dissolved in water and freeze-dried to give the 'basic fraction'.

Preparative gel filtration. A column of Sephadex G-50 $(100 \mathrm{~g}$, $90 \mathrm{~cm} . \times 3 \cdot 8 \mathrm{~cm}$.) was prepared with formic acid (90\%)-acetic acid-water $(1: 4: 45$, by vol.) as solvent. Portions of 'basic fraction' were dissolved in 5-10 $\mathrm{ml}$. of formic acid-acetic acid-water which contained DNPethanolamine $(1 \mathrm{mg}$. $/ 10 \mathrm{ml}$.) as a marker. In the fractionation illustrated in Fig. 3, $250 \mathrm{mg}$. of 'basic fraction' was applied and fractions $(10 \mathrm{ml}$.) were collected at a flow rate of $17 \mathrm{ml} . / \mathrm{hr}$. The elution volumes were dependent on the quantity of material applied to the column. With larger samples the polypeptides were somewhat retarded. Fractions were examined spectrophotometrically at $280 \mathrm{~m} \mu$ and by electrophoresis in polyacrylamide gel. Appropriate fractions were pooled and concentrated at temperatures not exceeding $35^{\circ}$, then freeze-dried.

Further purification of the polypeptides and proteins was achieved by repeated chromatography of the fractions on the above column or on a $150 \mathrm{~g}$. column $(133 \mathrm{~cm} . \times 3 \cdot 8 \mathrm{~cm}$. $)$ of Sephadex G-50. The fractionation procedure is outlined in Scheme 1.

Preparation of guinea-pig basic proteins and polypeptides. A similar 'basic fraction' was prepared from frozen guineapig brain by the procedures described above for bovine spinal cord. After a single passage of the guinea-pig 'basic fraction' through a column $(133 \mathrm{~cm} . \times 3.8 \mathrm{~cm}$.) of Sephadex G-50, the components separated into three fractions: a protein fraction (elution vol. 545-570 $\mathrm{ml}$.) and two polypeptide fractions (elution vols. $680-750 \mathrm{ml}$. and $810-890 \mathrm{ml}$. respectively). The last-named polypeptide fraction was studied.

Preparation of 'basic protein'. 'Basic protein' was extracted from freeze-dried bovine spinal cord by the method described by Kies (1965), which uses aq. chloroformmethanol $(2: 1, v / v)$ rather than acetone-light petroleum to defat freeze-dried nervous tissue. Each $30 \mathrm{~g}$. of cord was blended with $120 \mathrm{ml}$. of water and then extracted with 31 . of chloroform-methanol.

Influence of solvents on the composition of the 'basic fraction'. Samples of freeze-dried bovine spinal cord (10g.) were extracted with various solvents, and the 'basic fraction' was precipitated from acid extracts with acetone.

The freeze-dried cord was extracted with $200 \mathrm{ml}$. of phenol-acetic acid-water $(1: 1: 1, w / v / v)$. Phenol was removed with ether and the aqueous phase collected after the addition of $300 \mathrm{ml}$. of acetone-water $(1: 2 \mathrm{v} / \mathrm{v})$. The aqueous phase, $\mathrm{pH} 3 \cdot 5$, was added to 9 vol. of acetone and the precipitate collected and freeze-dried.

Samples of cord were extracted with a total of 1.51. of either chloroform-methanol $(2: 1, v / v)$ or acetone. The residue was homogenized with $0.02 \mathrm{~N}-\mathrm{HCl}(100 \mathrm{ml}$.), adjusted to $\mathrm{pH3} .0$ with $\mathrm{N}-\mathrm{HCl}$ and filtered. The filtrate was added to 9 vol. of acetone and the precipitate treated as above.

Guinea pigs were killed by exsanguination and their brains $(100 \mathrm{~g}$.) were treated, within a few minutes of being killed, with phenol-acetic acid-water $(1: 1: 1, w / v / v)$. After removal of phenol by repeated evaporation in the presence of water in a rotary evaporator, the extract was fractionated by the methods used to prepare 'basic fraction'.

Electrophoresis. Fractions were examined always by electrophoresis in polyacrylamide gel $(15 \%, \mathrm{w} / \mathrm{v})$ in formic acid-acetic acid-water (1:4:45, by vol.) containing $4 \mathrm{M}$ urea, $\mathrm{pH} 2.5$. The mobility of each zone relative to cytochrome $c$ was determined and expressed as the $M_{c}$ value (Carnegie, Lamoureux \& Bencina, 1967). Other buffers used for electrophoresis of purified polypeptides in polyacrylamide gel were: $0.06 \mathrm{M}$-veronal-4M-urea, $\mathrm{pH} 8.7$; $0.05 \mathrm{M}$-sodium acetate-4 M-urea, pH4.7; 0.05 M-sodium carbonate, $\mathrm{pH} 9 \cdot 4$ and 10.4 .

Amino acid analysis. Samples were hydrolysed at $105^{\circ}$ in vacuo with $6 \mathrm{~N}-\mathrm{HCl}$ for $22 \mathrm{hr}$. and analysed in a Spinco 120 B amino acid analyser. A correction of $10 \%$ for loss of serine and threonine was added to the results. Tryptophan 
was determined spectrophotometrically (Beaven \& Holiday, 1952).

Microanalysis. Analyses for $\mathrm{C}$ and $\mathrm{N}$ were carried out by the Australian Microanalytical Service, University of Melbourne.

Estimation of molecular weight. Gel filtration on a column of Sephadex G-50 (10 g., $34 \mathrm{~cm} . \times 1.8 \mathrm{~cm}$.) with formic acidacetic acid-water as solvent was used to estimate the molecular weight of the polypeptides. Polypeptides of known molecular weight used to calibrate the column are listed in Fig. 6. The effluents were examined spectrophotometrically and the extinction was recorded on a servorecorder at $280 \mathrm{~m} \mu$ or $230 \mathrm{~m} \mu$. Cube roots of the distribution coefficients $\left(K_{\mathrm{d}}\right)$ were calculated and plotted against the square roots of mol.wt. (Porath, 1963).

Basic protein was studied in the analytical ultracentrifuge. A $1 \%$ solution of basic protein in sodium acetate buffer, pH5.5, I 0.1, was centrifuged at $59780 \mathrm{rev} . / \mathrm{min}$. for $74 \mathrm{~min}$. at $20^{\circ}$.

Enzymic digestion. In a typical experiment, $3 \cdot 5 \mathrm{mg}$. of polypeptide fraction in $4 \mathrm{ml}$. of water was treated at $\mathrm{pH} 8.2$ with $50 \mu \mathrm{g}$. of trypsin in a Radiometer $\mathrm{pH}$-stat. A rapid uptake of $0.01 \mathrm{~N}-\mathrm{NaOH}$ occurred. The addition of $50 \mu \mathrm{g}$. of trypsin after $1 \frac{1}{2} \mathrm{hr}$. caused no increase in the rate of uptake of $\mathrm{NaOH}$. After $3 \mathrm{hr}$. digestion was stopped by adding $\mathrm{N}$-acetic acid to lower the $\mathrm{pH}$ to $\mathbf{3 . 9}$.

Samples of polypeptide fraction (1-2mg.) in $0.1 \mathrm{~m}$ ammonium acetate, pH 7·8, were treated with chymotrypsin $(20 \mu \mathrm{g}$.) for $2 \mathrm{hr}$. Digests were evaporated to dryness on a rotary evaporator at a temperature not greater than $35^{\circ}$. Peptide 'maps' were prepared as described in Figs. 7 and 8. Peptides and amino acids were detected as described by Easley (1965).

Assay of proteolytic activity. The proteolytic activity of freeze-dried bovine spinal cord, and of spinal cord after treatment with acetone or chloroform-methanol, was assayed by the method of Anson (1938) with acid-denatured haemoglobin as substrate at $\mathrm{pH} 3.5$ and $37^{\circ}$, and the FolinCiocalteu reagent for determining tyrosine.

Assay of encephalitogenic activity. Fractions were tested

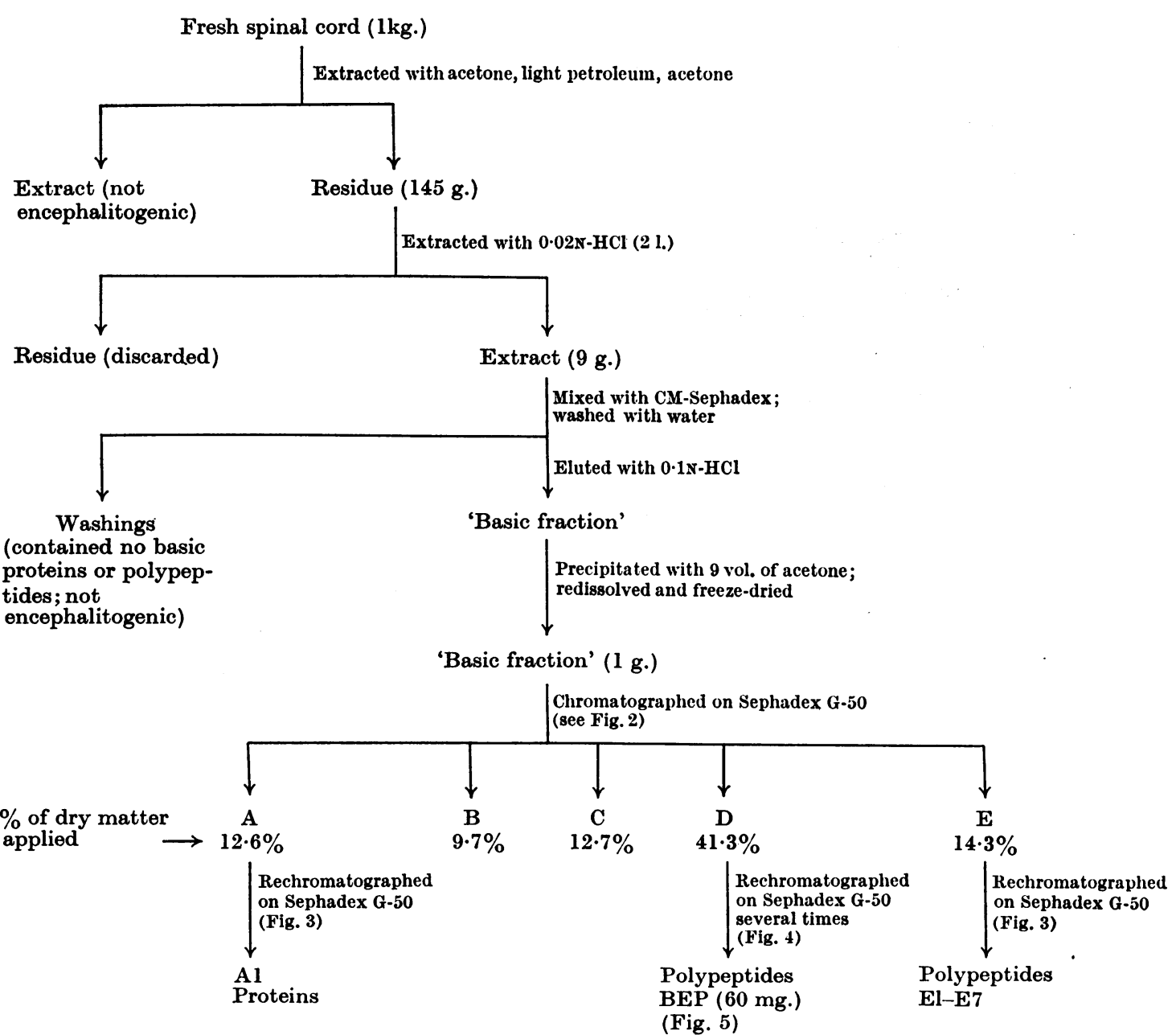

Scheme 1. Flow sheet for the isolation of basic proteins and polypeptides from bovine spinal cord. 
for their ability to produce EAE in guinea pigs. Each animal received one injection in the right hind footpad of $60 \mu$ l. of a saline solution of the fraction mixed with en equal volume of Freund's complete adjuvant. Animals were observed daily for clinical symptoms of EAE and killed when paralysed. If no symptoms developed, they were killed 21 days after immunization and brains and spinal cords removed for histological study. Further details are given by Lamoureux at al. (1967b).

\section{RESULTS}

A summary of the preparation of the 'basic fraction', which is a mixture of basic polypeptides and proteins, is shown in Scheme 1. A typical fractionation of this mixture on Sephadex G-50 is given in Fig. 2. Electrophoresis of the fractions (Fig. 1) indicated that even a single passage of the 'basic fraction' through the column resulted in considerable separation.

The smallest polypeptides, zone $\mathbf{E}$, were rechromatographed (Fig. 3) and zones. El and E6 tested for encephalitogenic activity. Since zone E6 appeared to have only slight activity (Table 1), attempts were made to isolate a homogeneous polypeptide from the mixture in zones E1 and E2. Zone D, which had essentially the same electrophoretic pattern as zones E1 and E2, and which was available in greater quantities, was used as the starting material for the isolation by repeated gelfiltration chromatography (Fig. 4). The elution pattern of the material finally selected for detailed study is shown in Fig. 5. For convenience in

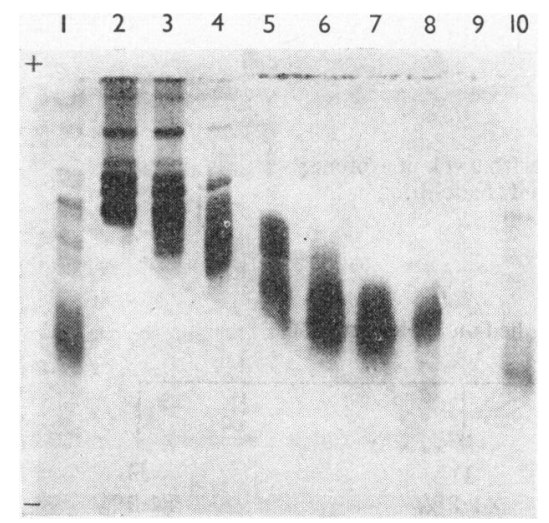

Fig. 1. Electrophoresis of fractions obtained by gel filtration of 'basic fraction' (Fig. 2) from bovine spinal cord. Electrophoresis was carried out in polyacrylamide gel $(15 \%, w / v)$ equilibrated in formic acid-acetic acid-water $(1: 4: 45$, by vol.) containing $4 \mathrm{M}$-urea, $\mathrm{pH} 2.5$ (conditions: $14 \mathrm{v} / \mathrm{cm}$.; $60 \mathrm{~mA}$ for $3.5 \mathrm{hr}$.). 1, 'Basic fraction'; fractions eluted at: 2, 330ml.; 3, 380ml.; 4, 430ml.; 5, 490ml.; 6, 550ml.; 7, $620 \mathrm{ml}$; 8, 700ml.; 9, $800 \mathrm{ml}$.; 10, 'basic fraction'. discussion of its chemical and immunological properties we refer to it as BEP.

When the protein zone (A) was rechromatographed to free it from polypeptides, only $11 \%$ of

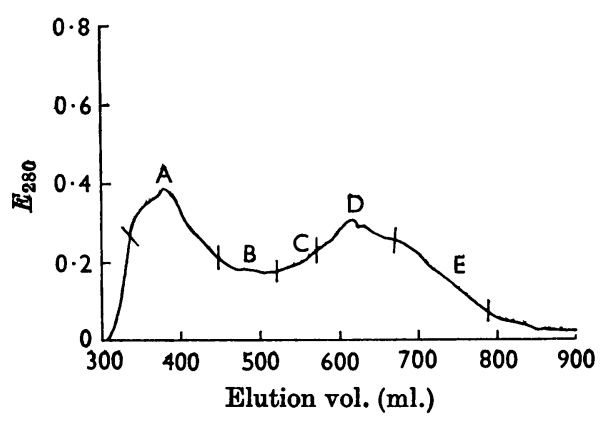

Fig. 2. Gel-filtration chromatography of 'basic fraction' ( $250 \mathrm{mg}$.) on a column of Sephadex G-50 $(90 \mathrm{~cm} . \times 3.8 \mathrm{~cm}$.) in formic acid-acetic acid-water (1:4:45, by vol.). Fractions ( $10 \mathrm{ml}$.) were collected at a flow rate of $17 \mathrm{ml} . / \mathrm{hr}$. and examined spectrophotometrically at $280 \mathrm{~m} \mu$. Fractions were pooled (A-E) as shown by the cross lines.

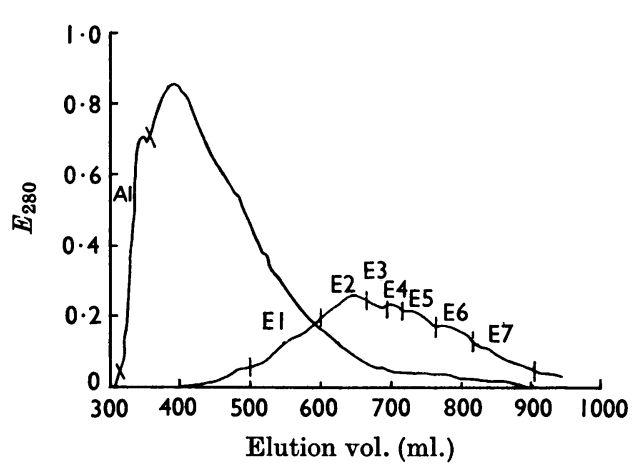

Fig. 3. Left-hand graph shows the chromatography of fraction A (see Fig. 2). The right-hand graph shows the chromatography of fraction $\mathbf{E}$. The fractions were chromatographed under the conditions described in Fig. 2.

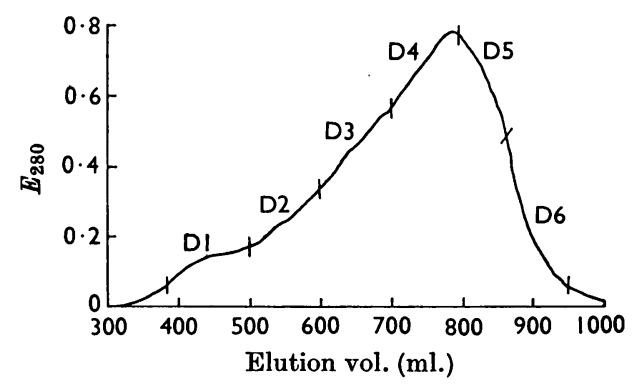

Fig. 4. Chromatography of fraction $\mathrm{D}$ under the conditions described in Fig. 2. 
the dry matter applied was recovered in zone Al (Fig. 3). Cytochrome c (mol.wt. 12400) was eluted slightly later than this zone on the same column, which suggested that zone Al was composed of proteins with mol.wt. greater than 12000 . Electrophoresis showed that the main component of zone Al was the same as the 'basic protein' prepared by the Kies (1965) method. Zone Al contained also at least five other electrophoretic components whose mobilities $\left(M_{c}\right)$ were between 0.2 and 1.0 . The encephalitogenic activity of zone $\mathrm{Al}$ is shown

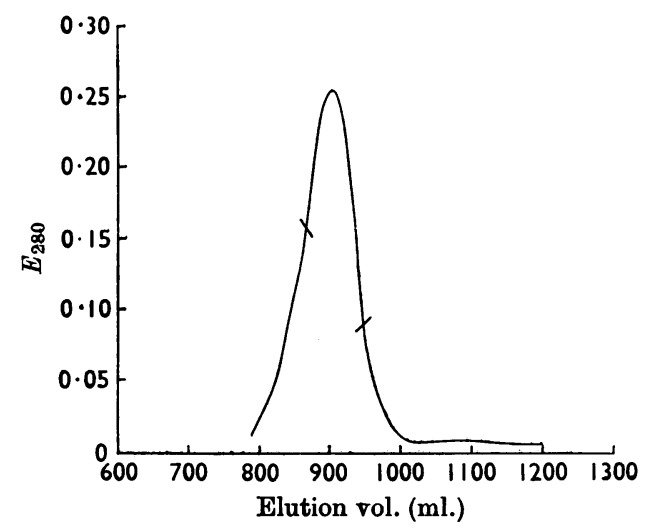

Fig. 5. Fractions D4 and D5 were rechromatographed several times on a column of Sephadex G-50 (133 cm. $\times$ $3.8 \mathrm{~cm}$.). The Figure shows the final chromatogram. Other conditions were described in Fig. 2. in Table 1. The amino acid composition of Al was similar to 'basic protein' (Table 2), except that Al contained $0.9 \%$ cystine.

Properties of BEP. Although a reasonably symmetrical peak was obtained with this fraction (Fig. 5), it was not homogeneous. Electrophoresis at $\mathrm{pH} 2.5$ showed a group of three polypeptides with only slight differences in their mobilities. It was not possible to separate these polypeptides by ion-exchange chromatography or by preparative gel electrophoresis.

At pH 2.5 the mobilities of the three polypeptide zones relative to cytochrome $c\left(M_{c}\right)$ were $1.90,1.95$ and $2 \cdot 00$. These zones had an average $M_{c} 1 \cdot 13$ at $\mathrm{pH} 4.5$ and 1.10 at $\mathrm{pH} 8.7$. At $\mathrm{pH} 10.4$, where cytochrome $c$ was isoelectric, BEP was resolved into three zones; two remained cationic, whereas the other moved slightly towards the anode.

From gel filtration on the preparative columns, and from an analytical column of Sephadex G-50 loaded with $1 \mathrm{mg}$. of BEP, it was possible to get an estimate of the molecular weight of BEP. From the calibration graph shown in Fig. 6, the molecular weights of the polypeptides present in BEP were estimated to be approx. 3500 .

The amino acid composition of BEP is given in Table 2. The composition of a polypeptide fraction (D4) from which BEP was isolated, and which had a closely similar amino acid composition and electrophoretic mobility, was studied in greater detail. Microanalysis showed : C, $47 \cdot 7 \%$; N, 17.6\%. From the amino acid analysis, recoveries were: N, $97.0 \% ; \mathrm{C}, 97.5 \%$. These recoveries rule out the

\section{Table 1. Encephalitogenic activity of basic proteins and polypeptides from extracts of bovine} spinal cord and guinea-pig brain tested in guinea pigs

Results are the ratio of number of animals showing clinical and histological signs of EAE to the number of animals immunized. All fractions were premixed with Freund's complete adjuvant. Day of onset of clinical symptoms is also given. Immunization of 12 animals with Freund's complete adjuvant alone, or with adjuvant plus $1 \mathrm{mg}$. of thyroglobulin, showed no clinical or histological symptoms of EAE.

\begin{tabular}{|c|c|c|c|c|c|c|c|c|c|}
\hline Dose $(\mu \mathrm{g}.) \ldots . .$. & & 50 & & & 10 & & & 1 & \\
\hline Fraction & Clinical & $\begin{array}{l}\text { Histo- } \\
\text { logical }\end{array}$ & $\begin{array}{c}\text { Day of } \\
\text { onset }\end{array}$ & Clinical & $\begin{array}{l}\text { Histo- } \\
\text { logical }\end{array}$ & $\begin{array}{c}\text { Day of } \\
\text { onset }\end{array}$ & Clinical & $\begin{array}{l}\text { Histo- } \\
\text { logical }\end{array}$ & $\begin{array}{c}\text { Day of } \\
\text { onset }\end{array}$ \\
\hline 'Basic fraction' & $4 / 5$ & $5 / 5$ & $11-13$ & - & - & - & - & - & - \\
\hline D & $21 / 26$ & $19 / 26$ & $13-16$ & $3 / 5$ & $4 / 5$ & 14-18 & $1 / 5$ & $4 / 5$ & 18 \\
\hline Al & $\mathbf{3} / \mathbf{5}$ & $4 / 5$ & $14-18$ & $4 / 5$ & $5 / 5$ & $13-17$ & $3 / 5$ & $5 / 5$ & $13-18$ \\
\hline E1 & $4 / 5$ & $4 / 5$ & $14-18$ & $4 / 5$ & $5 / 5$ & 14-18 & $2 / 5$ & $4 / 5$ & $16-19$ \\
\hline E6 & $2 / 5$ & $2 / 5$ & $16-17$ & $1 / 5$ & $1 / 5$ & 18 & $0 / 5$ & $0 / 5$ & - \\
\hline BEP & $22 / 26$ & $20 / 26$ & $11-16$ & $4 / 5$ & $5 / 5$ & $11-16$ & $4 / 6$ & $6 / 6$ & $14-16$ \\
\hline 'Basic protein' & $\mathbf{3} / \mathbf{6}$ & $5 / 6$ & $17-19$ & - & - & - & - & - & - \\
\hline $\begin{array}{l}\text { Guinea-pig } \\
\text { equivalent of } \\
\text { A1 }\end{array}$ & $4 / 6$ & $5 / 6$ & $13-19$ & $1 / 6$ & $2 / 6$ & 16 & - & - & 一 \\
\hline $\begin{array}{l}\text { Guinea-pig } \\
\text { equivalent of } \\
\text { El }\end{array}$ & $5 / 6$ & $6 / 6$ & $18-21$ & $6 / 6$ & $6 / 6$ & $11-17$ & - & 一 & - \\
\hline
\end{tabular}


presence of significant amounts of carbohydrates or long-chain fatty acids. Carnegie \& Lumsden (1967) found that a chromatographically and

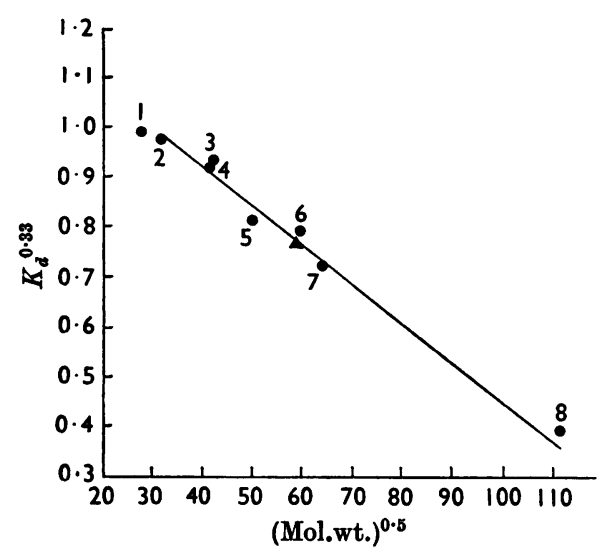

Fig. 6. Estimation of the molecular weight of BEP ( $\Delta$ ) by chromatography on Sephadex G-50. Reference polypeptides (๑) were: 1, Val-Tyr-His-Pro-Phe; 2, $\beta$-Asp1. Val5-angiotensin II; 3, $\alpha$-melanotrophin; 4, Asn-Arg-ValTyr-Val-His-Pro-Phe-His-Leu-Leu-Val-Tyr-Ser; 5, insulin, A chain; 6, insulin, $B$ chain; 7, clupeine $Z ; 8$, cytochrome $c$ (horse). Polypeptides 1, 2, 3 and 4 were gifts from Ciba Ltd., Basle, Switzerland, and 7 was from Dr T. Ando. For other details see the text. electrophoretically similar fraction had no phosphate and negligible carbohydrate. The ultraviolet spectrum of BEP was typical of a polypeptide containing tryptophan, tyrosine and phenylalanine and there was no evidence for any purine or pyrimidine residues. We conclude from these results that BEP is composed of amino acids and does not have any significant amounts of lipid, carbohydrate or nucleotide. Hence the encephalitogenic activity must be due to a particular sequence of amino acids.

The encephalitogenic activity of BEP is given in Table 1. Further information on the immunological and encephalitogenic properties of BEP are given by Lamoureux et al. (1967b), who showed that a very small dose (50ng.) of BEP produced EAE in guinea pigs. Neither BEP nor 'basic fraction' produced EAE in Wistar rats.

Properties of 'basic protein'. The 'basic protein' prepared from freeze-dried bovine spinal cord by the Kies (1965) method was obtained in a yield of approx. $0.5 \%$ of the dry matter. Complete extraction of 'basic protein' was not attempted.

On gel electrophoresis, even at high concentrations (50 mg./ml.), it showed a sharp zone with $M_{c}$ $0 \cdot 72$. Its encephalitogenic activity is given in Table 1 and its amino acid composition in Table 2. 'Basic protein' had the same electrophoretic mobility as the main component of zone Al, and as the equivalent zone from a similar fractionation of guinea-pig brain.

Table 2. Amino acid composition of bovine encephalitogenic polypeptide and 'basic protein'

\begin{tabular}{|c|c|c|c|c|c|c|}
\hline & & & Basic & rotein & & \\
\hline & $\begin{array}{c}\text { (moles/100 } \\
\text { moles of } \\
\text { amino acid) }\end{array}$ & ( $\mu$ mole/mg.) & $\begin{array}{c}\text { (moles/100 } \\
\text { moles of } \\
\text { amino acid) }\end{array}$ & ( $\mu$ moles/mg.) & Molar ratio & $\begin{array}{c}\text { Nearest } \\
\text { integer }\end{array}$ \\
\hline Lys & $8 \cdot 31$ & 0.616 & $7 \cdot 94$ & 0.593 & $11 \cdot 8$ & 12 \\
\hline His & $6 \cdot 31$ & 0.467 & $5 \cdot 71$ & 0.425 & 8.7 & 9 \\
\hline Arg & $9 \cdot 34$ & 0.678 & $9 \cdot 45$ & 0.703 & $14 \cdot 1$ & 14 \\
\hline Total basic & $23 \cdot 96$ & & $23 \cdot 10$ & & & 35 \\
\hline Asp & $5 \cdot 50$ & 0.407 & $6 \cdot 85$ & 0.511 & $10 \cdot 2$ & 10 \\
\hline Glu & $6 \cdot 84$ & 0.507 & $6 \cdot 76$ & 0.505 & $10 \cdot 1$ & 10 \\
\hline Total acidic & $12 \cdot 34$ & & $13 \cdot 61$ & & & 20 \\
\hline $\mathrm{NH}_{3}$ & $9 \cdot 48$ & $0 \cdot 703$ & $9 \cdot 62$ & 0.716 & $14 \cdot 3$ & 14 \\
\hline Thr & $4 \cdot 86$ & $0 \cdot 360$ & $4 \cdot 42$ & $0 \cdot 330$ & $6 \cdot 6$ & 7 \\
\hline Ser & 11.56 & 0.857 & $9 \cdot 84$ & 0.735 & $14 \cdot 7$ & 15 \\
\hline Pro & $7 \cdot 37$ & 0.546 & $7 \cdot 39$ & 0.552 & $11 \cdot 1$ & 11 \\
\hline Gly & $13 \cdot 12$ & 0.972 & $14 \cdot 46$ & 1.080 & 20.2 & 20 \\
\hline Ala & $10 \cdot 42$ & $0 \cdot 772$ & $8 \cdot 41$ & 0.575 & $11 \cdot 5$ & 12 \\
\hline$\frac{1}{2} \mathrm{CyS}$ & 0.00 & 0.000 & 0.00 & 0.000 & 0.0 & $\mathbf{0}$ \\
\hline Val & $1 \cdot 10$ & 0.081 & $2 \cdot 15$ & $0 \cdot 161$ & $3 \cdot 2$ & $\mathbf{3}$ \\
\hline Met & $1 \cdot 18$ & 0.088 & 1.05 & 0.079 & $1 \cdot 6$ & 2 \\
\hline Ile & $1 \cdot 12$ & 0.082 & $1 \cdot 78$ & $0 \cdot 133$ & $2 \cdot 7$ & $\mathbf{3}$ \\
\hline Leu & 6.07 & 0.500 & $6 \cdot 17$ & 0.460 & $9 \cdot 2$ & 9 \\
\hline Tyr & $2 \cdot 97$ & $0 \cdot 222$ & $2 \cdot 39$ & $0 \cdot 179$ & $3 \cdot 6$ & 4 \\
\hline Phe & $3 \cdot 12$ & $0 \cdot 231$ & $4 \cdot 60$ & $0 \cdot 344$ & 6.9 & 7 \\
\hline Trp & $0 \cdot 80$ & 0.060 & 0.62 & 0.050 & $1 \cdot 0$ & $\begin{array}{r}1 \\
149\end{array}$ \\
\hline
\end{tabular}


'Basic protein' in the ultracentrifuge gave a single peak with $S$ approx. $0.7 \mathrm{~s}$, which suggests a mol.wt. less than 10000, yet on Sephadex G-50 it had an elution volume equivalent to that of a protein about mol.wt. 15000. Caspary \& Field (1965) also noted a similar inconsistency and suggested that their basic protein from human brain might have an unusual partial specific volume. Amino acid analysis (Table 2) suggested mol.wt. 16523. For this molecular weight and content of lysine and arginine a total of 27 peptides should be found in a peptide 'map' of a tryptic digest; 25 distinct spots were observed.

Lumsden et al. (1966) and Caspary \& Field (1965) claimed that exposure of basic proteins from nervous tissue to an alkaline $\mathrm{pH}$ caused peptides to be released. We found that mild conditions (e.g. $0.026 \mathrm{M}$-sodium tetraborate, $\mathrm{pH} 9.2$, for $23 \mathrm{hr}$. at room temperature) failed to cause any significant degradation of our 'basic protein'. However, stronger alkali ( $\mathrm{N}$-sodium hydroxide at $4^{\circ}$ for $48 \mathrm{hr}$.) completely converted 'basic protein' into a complex mixture of polypeptides with $M_{c}$ values between 1.25 and 1.8 .

Comparison of digests of BEP and 'basic protein'. A peptide 'map' of a tryptic digest of BEP showed

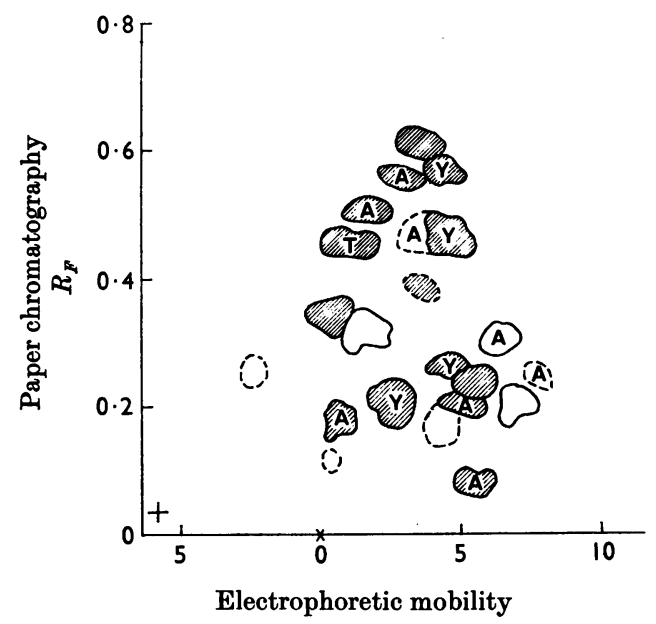

Fig. 7. Peptide 'map' of a tryptic digest of BEP. Electrophoresis of a $250 \mu \mathrm{g}$. sample in $2.5 \mu \mathrm{l}$. was carried out in pyridine-acetic acid-water (10:3:500, by vol.), $\mathrm{pH} 4$, on Whatman $3 \mathrm{MM}$ paper at $50 \mathrm{v} / \mathrm{cm}$. for $30 \mathrm{~min}$. Chromatography was with butan-1-ol-pyridine-acetic acid-water (15:10:3:12, by vol.) and peptides were located with $0.3 \%$ ninhydrin in collidine-chloroform $(1: 100, v / v$.). Faint spots are indicated by broken lines. Hatched areas indicate peptides common to BEP and 'basic protein'. Spots which gave a yellowish colour with ninhydrin are indicated by $Y$, spots containing arginine by $\mathbf{A}$ and tryptophan by $\mathrm{T}$.
16 strong and five or six faint spots with ninhydrin (Fig. 7). Arginine was present in eight of these peptides and tryptophan in one. The finding of 16 peptides in the tryptic digest was consistent with BEP being a mixture of three polypeptides. Tryptic digests of basic protein showed 25 distinct spots reacting with ninhydrin. At least 14 of these spots were identical with those on a peptide 'map' of tryptic digest of BEP with respect to $R_{F}$, mobility, colour with ninhydrin and reactions for arginine and tryptophan, where present.

Tryptic digests of BEP and basic protein were fractionated on a column $(34 \mathrm{~cm} . \times 1.8 \mathrm{~cm}$.) of Sephadex G-25 to remove any traces of undigested polypeptide or protein. Both of these digests were still highly encephalitogenic. The digest of 'basic protein', which is being studied in greater detail, caused clinical signs of EAE in five out of six guinea pigs injected with a dose equivalent to $20 \mu \mathrm{g}$. of the original protein.

Kies, Thompson \& Alvord (1965) claimed that tryptic digestion destroyed the encephalitogenic activity of their basic protein from guinea-pig brain, but Caspary \& Field (1965) found that the activity of a basic protein from human brain was only partially destroyed by trypsin.

Peptides from chymotryptic digests of BEP and basic protein were studied by a peptide-'mapping' technique in which they were first separated according to molecular size and then by paper chromatography (Carnegie, 1965). Peptides in the chymotryptic digests appeared to range in size from dipeptides (or free amino acids) to peptides. of 15 amino acids (Fig. 8). Again there were many peptides common to basic protein and BEP. Chymotryptic digests were not tested for encephalitogenic activity.

Origin of $B E P$. From peptide 'maps' of the digests of BEP and basic protein it appears likely that considerable sections of the amino acid sequences are identical and that the polypeptides present in BEP could have been derived from the 'basic protein' during their isolation. To ascertain if these polypeptides were present in normal central nervous tissue, we extracted with phenol-acetic acid-water $(1: 1: 1, w / v / v)$. This is a highly dissociating solvent which has the added advantage that it denatures proteolytic enzymes (Bagdasarian, Matheson, Synge \& Youngson, 1964). In extracts prepared with this solvent from both freeze-dried spinal cord and fresh guinea-pig brain, no small polypeptides were observed, but the main component was the basic protein of $M_{c} \mathbf{0 \cdot 7 2}$. However, the yield of basic protein was low $(8 \mathrm{mg} . / \mathrm{g}$. of freeze-dried cord).

There has been considerable controversy about the presence of encephalitogenic polypeptides in acid extracts of nervous tissue (see the Discussion 


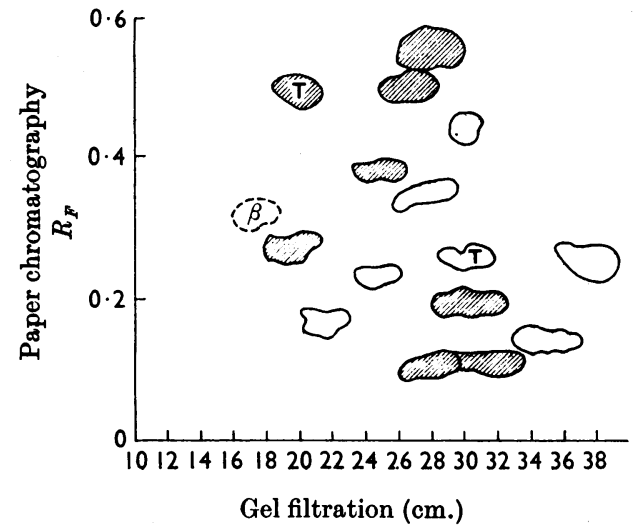

Fig. 8. Peptide 'map' of a chymotryptic digest of BEP. First stage, micro-gel-filtration of $500 \mu \mathrm{g}$. of sample in $10 \mu \mathrm{l}$. on a column of Sephadex G-25 $(60 \mathrm{~cm} . \times 3 \mathrm{~mm}$.) with phenol-acetic acid-water $(1: 1: 1, w / v / v)$ as solvent. Zones (2cm.) were transferred to a sheet of Whatman 3MM paper for chromatography with the solvent described in Fig. 7. $\beta$-Alanine $(\beta)$ was included as a reference marker. Hatched areas indicate peptides common to BEP and 'basic protein'. Spots which contained tryptophan are indicated by $\mathrm{T}$.

section). The solvent used for defatting the tissue appeared to influence the composition of the acid extract. Kies (1966) suggested that when chloroform-methanol was used to defat freezedried brain an acid proteinase was inactivated. We investigated the composition of the basic fraction after defatting freeze-dried bovine spinal cord with either acetone or chloroform-methanol.

After treatment with chloroform-methanol there was a yield of $69 \mathrm{mg}$. of dry matter $/ \mathrm{g}$. of freeze-dried cord in the extract prepared at $\mathrm{pH} 3 \cdot 0$, compared with a yield of $16 \mathrm{mg} . / \mathrm{g}$. after treatment with acetone. The compositions of the acid extracts were markedly different. Electrophoresis of extracts from cord treated with chloroform-methanol showed a strong band corresponding to 'basic protein' $\left(M_{c} \mathbf{0 . 7 2}\right)$ and much lower concentrations of other basic proteins. There was no trace of BEP even when five times the normal sample was applied to the gel. However, there were small amounts of larger polypeptides corresponding to those with mol.wt. between 8000 and 10000 . After treatment of the cord with acetone, the acid extract contained several smaller polypeptides in addition to the protein with $M_{c} \mathbf{0 . 7 2}$. However, the yield of polypeptides equivalent to BEP was much lower than that obtained when fresh cord rather than freezedried cord was used as the starting material for extraction with acetone.
Proteolytic activity of freeze-dried cord at $\mathrm{pH} 3.5$, with haemoglobin as substrate, was $0.019 \mu$ mole of tyrosine liberated $/ \mathrm{min} . / 25 \mathrm{mg}$. of cord. Cord treated with acetone had an activity $146 \%$ of this value and $26 \%$ after chloroform-methanol treatment.

From these results it appears likely that polypeptides could be derived from proteins during extraction with dilute acid. The amino acid compositions of the polypeptide fractions E1 and E6 from bovine spinal cord were similar, which suggested a common origin. Strong evidence that BEP is derived from the 'basic protein' with $M_{c}$ 0.72 comes from a comparison of peptide 'maps'. In addition BEP and 'basic protein' are related immunochemically by cross-reaction in delayed hypersensitivity tests (Lamoureux et al. 1967b). We conclude that the polypeptides which we have isolated from bovine spinal cord are not normal components of nervous tissue but appear to be produced by proteolysis of a basic protein during extraction with acid.

Isolation of guinea-pig basic proteins and polypeptides. These basic polypeptides $\left(M_{c} \mathbf{1} \cdot 6-1 \cdot 8\right)$ and proteins $\left(M_{c} 0 \cdot 2-0 \cdot 8\right)$ were isolated mainly to provide homologous encephalitogens whose immunological properties in guinea pigs could be compared with the equivalent bovine fractions. They were of particular interest because, unlike the bovine fractions, they could produce EAE in Wistar rats (Lamoureux et al. 1967b). The amino acid compositions of these fractions were essentially similar to the respective bovine fractions. Their encephalitogenic activity in guinea pigs is shown in Table 1. Peptide 'maps' of the tryptic digests of guinea-pig polypeptides showed several spots which were also present in 'maps' of tryptic digests of BEP and bovine 'basic protein'.

\section{DISCUSSION}

The eventual aim of this investigation is the isolation of the smallest peptide capable of inducing $\mathrm{EAE}$, in other words the isolation of the encephalitogenic determinant. In this paper we describe the isolation and partial characterization of an encephalitogenic fraction (BEP) composed of polypeptides of mol.wt. about 3500. It appears that an even smaller encephalitogen may be isolated from tryptic digests of BEP and encephalitogenic basic protein. Encephalitogenic polypeptides are an addition to the growing list of polypeptides of low molecular weight which are capable of inducing an immunological response (cf. Dietrich, 1966).

For some years there has been considerable controversy about the molecular size of the encephalitogenic compounds in extracts of central nervous tissue. Mixtures of encephalitogenic poly. 
peptides and proteins were extracted from spinal cord that had been partially defatted with acetone (Robertson et al. 1962; Lumsden et al. 1964, 1966; Carnegie \& Lumsden, 1966, 1967; Nakao \& RobozEinstein, 1965; Kibler, Fox \& Shapira, 1964). Mild procedures were used and it was thought that the polypeptides were not produced from proteins during isolation (Carnegie \& Lumsden, 1967). However, when nervous tissue was partially defatted with chloroform-methanol encephalitogenic basic proteins were consistently isolated (Kies, 1965; Wolfgram, 1965; Caspary \& Field, 1965). From the results in the present paper it appears that this difference can be explained by the presence of an acid proteinase which is active after dehydrating and defatting with acetone, whereas the activity of this proteinase in nervous tissue treated with chloroform-methanol is much less. Kies (1966) came to the same conclusion. During extraction with acid this proteinase probably hydrolyses a basic protein of myelin to produce polypeptides. It has also been observed that polypeptides may be produced from this basic protein under alkaline conditions (cf. Lumsden et al. 1966).

After our experiments were concluded, Nakao, Davis \& Roboz-Einstein $(1966 a, b)$ demonstrated that an encephalitogenic basic protein (mol.wt. 16000) from bovine spinal cord could be converted at $\mathrm{pH} 3.2$ by a proteinase present in acetone-dried powders into a mixture of polypeptides, two of which were isolated and found to be encephalitogenic. They were larger (mol.wt. 14000 and 7600) than BEP and probably corresponded to our fractions $B$ and $C$.

Multiple sclerosis, a demyelinating disease of man, may be an autoimmune disease somewhat similar to EAE (Paterson, 1965). It is not clear how the antigens could be released from myelin and induce an immune response. Kornguth \& Anderson (1965) have evidence, from studies with ferritin-labelled antibodies, that many of the antigenic determinants of myelin are blocked in the intact tissue. Injury or inflammation in the central nervous system might release acid proteinases from lysosomes (Lajtha \& Marks, 1966), which, acting as they do in vitro, could cause proteolysis of myelin proteins with the liberation of polypeptides. These polypeptides, which we have shown to be encephalitogenic in animals, might be important in the initiation of multiple sclerosis.

One lesson from this work is that in the isolation of polypeptides from nervous tissue greater care should be taken to avoid proteolysis during extraction with acid. It might be valuable to re-examine the extraction of hormonal releasing factors, which are polypeptides (Guillemin, 1964), from the hypothalamus with a dissociating and denaturing solvent such as phenol-acetic acid-water (Synge, 1964).

There is now strong evidence that the encephalitogenic basic protein is a component of myelin. Laatsch et al. (1962) isolated the same basic protein from myelin. Rauch \& Raffel (1964) and Kornguth \& Anderson (1965) showed by immunofluorescence techniques that basic protein was localized in myelin. The basic protein which we isolated had a similar sedimentation coefficient and amino acid composition to the basic protein isolated from purified myelin (Lowden, Moscarello \& Morecki, 1966). These workers found that this protein accounted for only $1 \%$ of the total dry matter of myelin. It may have a role in maintaining the structure of the myelin sheath, perhaps in association with acidic lipids. It may possibly have a more active role in nervous tissue as MoIlwain, Woodman \& Cummins (1961) found that basic proteins (histones and protamines) could alter the response of nerve cells to electrical stimuli. This basic protein from myelin has a different amino acid composition from the total histone fraction obtained from isolated nuclei of brain (Piha, Cuénod \& Waelsch, 1966). The chief differences are in a lower content of histidine, serine and glycine in histones.

Our 'basic protein', from bovine spinal cord, was closely similar in amino acid composition to that isolated by Wolfgram (1965) and Nakao et al. (1966a) from bovine central nervous system. The amino acid composition is similar to that of encephalitogenic basic proteins from human (Caspary \& Field, 1965; Wolfgram, 1965) and guinea-pig central nervous tissue (Kies, 1965), but there are differences in the amounts of some of the amino acids. Kornguth \& Anderson (1965) have shown that the basic proteins of myelin from several mammals, fowls and frogs are similar by immunohistochemical techniques.

This investigation w as supported by grant no. 421 from the National Multi le Sclerosis Society, New York, and by a grant from the $\mathbf{M}$;dical Research Funds of the University of Melbourne. We thank Mr S. Modrich for technical assistance.

\section{REFERENCES}

Anson, M. L. (1938). J. gen. Physiol. 22, 79.

Bagdasarian, M., Matheson, N. A., Synge, R. L. M. \& Youngson, M. A. (1964). Biochem. J. 91, 91.

Beaven, G. H. \& Holiday, E. R. (1952). Advanc. Protein Chem. 7, 319.

Carnegie, P. R. (1965). Nature, Lond., 206, 1128.

Carnegie, P. R., Lamoureux, G. \& Bencina, B. (1967). Nature, Lond. 214, 407.

Carnegie, P. R. \& Lumsden, C. E. (1966). Nature, Lond., 209, 1354. 
Carnegie, P. R. \& Lumsden, C. E. (1967). Immunology, 12, 133.

Caspary, E. A. \& Field, E. J. (1965). Ann. N.Y. Acad. Sci. $122,182$.

Dietrich, F. M. (1966). Int. Arch. Allergy, N.Y., 30, 497.

Easley, C. W. (1965). Biochim. biophys. Acta, 107, 386.

Guillemin, R. (1964). Recent Progr. Hormone Res. 20, 89.

Hottle, G. A., Nedzel, G. A., Wright, J. T. \& Bell, J. F. (1949). Proc. Soc. exp. Biol., N.Y., 72, 289.

Kibler, R. F., Fox, R. H. \& Shapira, R. (1964). Nature, Lond., 204, 1273.

Kies, M. W. (1965). Ann. N.Y. Acad. Sci. 122, 161.

Kies, M. W. (1966). Proc. 5th int. Congr. Neuropathology, Zurich, p. 257. Ed. by Lüthy, F. \& Bischoff, A. Zurich: Exerpta Medica International Congress Ser. no. 100.

Kies, M. W., Murphy, J. B. \& Alvord, E. C. (1961). In Chemical Pathology of the Nervous System, p. 197. Ed. by Folch-Pi, J. Oxford: Pergamon Press Ltd.

Kies, M. W., Thompson, E. B. \& Alvord, E. C. (1965). Ann. N.Y. Acad. Sci. $122,148$.

Kornguth, S. E. \& Anderson, J. W. (1965). J. Cell Biol. 26, 157.

Laatsch, R. H., Kies, M. W., Gordon, S. \& Alvord, E. C. (1962). J. exp. Med. 115, 777.

Lajtha, A. \& Marks, N. (1966). In Protides of the Biological Fluids, vol. 13, p. 103. Ed. by Peeters, H. Amsterdam: Elsevier Publishing Co.

Lamoureux, G., Carnegie, P. R. \& McPherson, T. A. (1967a). Immunochemistry (in the Press).

Lamoureux, G., Carnegie, P. R., McPherson, T. A. \& Johnston, D. (1967b). Clin. exp. Immunol. (in the Press).
Lamoureux, G., McPherson, T. A. \& Carnegie, P. R. (1967c). Clin. exp. Immunol. 2, 253.

Lamoureux, G., McPherson, T. A., Carnegie, P. R. \& Mackay, I. R. (1967d). Clin. exp. Immunol. (in the Press).

Lowden, J. A., Moscarello, M. A. \& Morecki, R. (1966). Canad. J. Biochem. 44, 567.

Lumsden, C. E., Robertson, D. M. \& Blight, R. (1964). Z. Immun Forsch. 126, 168.

Lumsden, C. E., Robertson, D. M. \& Blight, R. (1966). J. Neurochem. 13, 127.

McIlwain, H., Woodman, R. J. \& Cummins, J. T. (1961). Biochem. J. 81, 79.

Nakao, A., Davis, W. J. \& Roboz-Einstein, E. (1966a). Biochim. biophys. Acta, 130, 163.

Nakao, A., Davis, W. J. \& Roboz-Einstein, E. (1966b). Biochim. biophys. Acta, 130, 171.

Nakao, A. \& Roboz-Einstein, E. (1965). Ann. N.Y. Acad. Sci. $122,171$.

Paterson, P. Y. (1965). In Immunological Diseases, p. 788. Ed. by Samter, M. Boston: Little, Brown and Co.

Paterson, P. Y. (1966). Advanc. Immunol. 5, 131.

Piha, R. S., Cuénod, M. \& Waelsch, H. (1966). J. biol. Chem. 241, 2397.

Porath, J. (1963). Pure appl. Chem. 6, 233.

Rauch, H. C. \& Raffel, S. (1964). J. Immunol. 92, 452.

Robertson, D. M., Blight, R. \& Lumsden, C. E. (1962). Nature, Lond., 196, 1005.

Synge, R. L. M. (1949). Quart. Rev. chem. Soc., Lond., 8, 245. Synge, R. L. M. (1964). Metabolism, 13, 969.

Wang, S.-S. \& Carpenter, F. H. (1965). J. biol. Chem. $240,1619$.

Wolfgram, F. (1965). Ann. N.Y. Acad. Sci. 122, 104. 